\title{
ATTITUDES AND BEHAVIORS OF ELDERLY INDIVIDUALS TOWARDS END-OF-LIFE DECISIONS
}

Turkish Journal of Geriatrics

DOI: 10.31086/tjgeri.2020.142

2020; 23(1): 90-99

- Deniz SAY ŞAHIN ${ }^{1}$ (D)

n Nüket ÖRNEK BÜKEN² D
CORRESPONDANCE

Deniz SAY ŞAHIN

Mehmet Akif Ersoy University, Faculty of

Economics and Administrative Sciences, Social

Work, Burdur, TURKEY.

Phone: +905052362620

e-mail: saysahind@mehmetakif.edu.tr

Received: 17/10/2019

Accepted: 23/02/2020

${ }^{1}$ Mehmet Akif Ersoy University,Faculty of

Economics and Administrative Sciences,

Social Work, Burdur, TURKEY.

${ }^{2}$ Hacettepe University, Medical School,

History of Medicine and Medical Ethics,

Ankara, TURKEY.

\section{Abstract}

Introduction: Elderly individuals frequently face end-of-life decisions. These decisions create moral burden for the family and health personnel. Aim of this study is determine the opinions of elderly about end-of-life decisions, which will act as a guide for physicians and families in clinical decision-making processes.

Materials and Method: Standardized Mini Mental Test was applied to 650 elderlies, and 448 participants with a test score 27 or more were interviewed between 1 May 2017 and 1 January 2019 using questionnaires including sociodemographic data form and scenarios that would determine their end-of-life decisions. Only statistically significant $(P \leq 0.05)$ results were presented in the results section.

Results: $72.5 \%(n=325)$ of the participants stated that they should be informed about medical diagnosis, $70.1 \%(n=314)$ stated that decision of informing the family should be left to patient and physician should inform the patient in any case. It was found that being familiar with the physician for a long time was important in fulfilling patient requests, and $79 \%(n=354)$ of the participants could consider leaving a living will and appointing a medical guardian.

Conclusion: Not talking to elderly patients with the judgment that they will not understand the concepts of elderly care, not seeing them as a decision-maker in treatment and care decisions, letting relatives make the decisions and applying these decisions are unacceptable attitudes for elderly individuals who have good mental health.

Keywords: Ageds; Advance Directives; Clinical Decision-Making; PhysicianPatient Relations; Attitude. 


\section{INTRODUCTION}

Since elderly individuals are closer to end of their expected lives, they are more likely to face situations where difficult decisions about health care have to be given. Therefore, when elderly people need health care, they frequently face end-of-life situations and they are often unable to make these decisions themselves. End-of-life care decisions often lead to additional stress, especially for elderly patients, and often don't reflect the patient's wishes correctly $(1,2)$. Who should be decision-maker in these situations? Herein, does the fact that care is pre-planned by patient, having left a living will, or having proxy to decide on their behalf facilitates their end-of-life decision making and care? All these questions make concepts of living will, advance directive, and durable power of attorney more prominent in elderly care.

Although concepts and practices such as living will, advanced directives, and durable power of attorney seem to overlap, the rationale for applying each in clinical setting and related application methods differ. End-of-life treatment preferences, future care choices, interviews with family and health care staff can be considered as part of advanced directives. Advanced directives should be clear and specific enough to guide the future clinical decisions. Living will direct the physicians about situations in which the patient wants to stop or withdraw his/her life support. Living will can only be used in fatal diseases and patient has to be aware of the decision and his/her medical condition. The situation is slightly different for durable power of attorney. Here, patient is unable to make decisions on his or her own, and appoints a proxy who can make medical decisions on his or her behalf. In contrast to the living will, the patient can be suffering from mental capacity loss or fatal disease in this case $(2,3)$. Individuals suffering from mental or physical capacity loss as a result of accidents, illnesses, or serious disabilities that may happen in the future will also cause difficulties in communication. For this reason, it is important that individuals declare the practices that they want or don't want to be performed on them while they are healthy, or declare who they want to be decision-maker when they become unable to make decisions for themselves. Furthermore, it's also true that participation of elderly individuals in medical decisions isn't at the desired level even if they don't have mental problems. Families ask physicians to tell them the diagnosis first $(4,5)$. However, Article 24 of the Patient Rights Regulation in our country requires the consent of the patient in medical interventions and it is essential for the patient to know its illness (6). This situation is sometimes just the opposite. Physicians prefer to talk with the family of older adults instead of themselves, for reasons such as lack of time, thinking that the patient cannot understand its condition, or feeling uncomfortable while saying the undesirable diagnosis, which completely eliminates the decision-making of an older adult having good mental health. However, it should be known that such practices contradict the Patient Rights Regulation in our country because Article 24 of the regulation indicates "even in cases where the legal representative's consent is sufficient, the young or restricted patient shall be enabled to participate in the information process and decisions about the treatment as much as possible to the extent that it can understand what has been told and is allowed to speak" (Patient Rights Regulation, Article 24) (6). In addition, for recurrent diseases where the competency is lost from time to time (which is frequently encountered in older adults due to dementia), there is the phrase in the same regulation that "prior requests of a patient, who is unable to explain its request during a medical intervention, regarding the medical intervention shall be taken into consideration". For this reason, it is important to know the decisions, wishes, and attitudes of elderly patients, who are at the last stage of their lives, about their ends, which will save the patient and family from many legal and ethical dilemmas. There are concerns about their deputies to decide on their behalf, as well as the predictable nature of both the serious illnesses of older adults and the 
decrease in their cognitive and voluntary abilities. This reveals significant benefits in the use of advance directives of the older adults for their care. Such directives include Authorization Statement - Representative Consent documents and Testament. Interestingly, most of the empirical research on both proxy decisions and advance directives focused on older adults. Unfortunately, such research in our country has not been made specifically for age groups. The lack of applications such as the living will, advance directive, durable power of attorney and the fact that their legal grounds have not been yet prepared are also important obstacles regarding the end of life decisions. In our country, there are a limited number of studies examining physician and patient attitudes regarding end-of-life decisions. Odabasi and Buken's study, "Informed Consent and Ethical Decision Making at the End of Life: Hacettepe Example", is an important resource for discussing the ethical decisions of physicians and patients at the HUTF hospital and the problem of autonomy. In the case of Hacettepe, physicians and patients prefer the authority and decision-making of the family and physician to the autonomy of the patient (7).

There are no studies in Turkey that reveal the opinions of elderly individuals about being told about bad diagnosis, living will, and durable power of attorney. Therefore, in this study, we tried to determine the opinions of elderly individuals about end-of-life decisions to act as a guide to physicians and families in clinical decision-making processes.

\section{MATERIALS AND METHOD}

\section{Sampling}

The population of the study consisted of elderly individuals living in the city center of Burdur. Considering the population of 11,360 individuals, prevalence of $50 \%$, sampling error rate of 0.05 and confidence interval of $95.0 \%$, the minimum sample size, which represents the population in the Epi-info programme, was calculated to be 378 . In this study, Standardized Mini Mental Test (SMMT) was applied to 650 people aged 65 years and over. Face-to-face interviews were conducted and questionnaires were applied to total of 448 volunteer participants with a test score of $\geq 27$ between May 1, 2017 and January 1, 2019, and only statistically significant results $(P \leq 0.05)$ were presented in the Results section.

\section{Data Collection Tools}

SMMT was developed by Folstein et al. in 1975 for the grading of cognitive disorders (8). Turkish validity and reliability of test was studied by Gungen et al. (2002) and normative values were determined. The patient receives a maximum of 30 and a minimum of 0 points at the end of the test. The critical score here is 27 or 24 . Patients with a score below 27 are considered to have cognitive impairment (9).

Sociodemographic data form prepared by researchers was used to collect data such as age, gender, marital status, education, social security, and income status of participants.

Scenarios in the questionnaire form used in this study to determine attitudes of elderly individuals towards end-of-life decisions were applied to participants by obtaining the necessary permissions from Ruhnke et al. (2000), which was adapted to Turkish by Buken and Balseven $(10,3)$. These scenarios questioning end-of-life decisions were selected because they are far from medical terminology and easy to understand for older adults and are designed to measure attitudes only, independent of acts and practices of the current country.

\section{Analysis of Data}

All statistical analyses were performed using Statistical Package for The Social Science v20.0. Descriptive analyses and Chi Square analysis were used to evaluate the data.

\section{Ethical considerations}

This study was approved by Ethics Committee of Mehmet Akif Ersoy University 
(Date:08.03.2017-Number: GO2017/55).

\section{RESULTS}

The examination of the demographic characteristics of the participants revealed that $38.2 \%$ were male, $33.3 \%$ were primary school graduates, $62.5 \%$ were married, $100 \%$ had a regular income, $83 \%$ had social security, and $53.1 \%$ had income equal to their expenses. The mean age of the participants was $71.6 \pm 3.4$ and mean SMMT score was $29.6 \pm$ 0.2 (Table 1).

Table 1. Sociodemographic Characteristics of the Participants.

\begin{tabular}{|c|c|c|c|}
\hline Characteristic & Groups & Number (n) & Percentage (\%) \\
\hline \multirow{2}{*}{ Age Group } & $65-74$ & 305 & 68,1 \\
\hline & 75 and over & 143 & 31,9 \\
\hline \multirow{2}{*}{ Sex } & Female & 277 & 61,8 \\
\hline & Male & 171 & 38,2 \\
\hline \multirow{3}{*}{ Marital Status } & Married & 280 & 62,5 \\
\hline & Widowed & 154 & 34,4 \\
\hline & Divorced & 14 & 3,1 \\
\hline \multirow{4}{*}{ Education } & Illiterate & 83 & 18,5 \\
\hline & Primary School & 149 & 33,3 \\
\hline & $\begin{array}{r}\text { Middle and High } \\
\text { school }\end{array}$ & 64 & 14,2 \\
\hline & University & 152 & 33,9 \\
\hline \multirow{2}{*}{ Regular Income } & Yes & 448 & 100 \\
\hline & No & 0 & 0 \\
\hline \multirow{2}{*}{ Social Security } & Yes & 372 & 83 \\
\hline & No & 76 & 17 \\
\hline \multirow{3}{*}{ Income Status } & Less than expenses & 134 & 29,9 \\
\hline & Equal to expenses & 238 & 53,1 \\
\hline & More than expenses & 76 & 17 \\
\hline \multirow{4}{*}{ Mini Mental Test Score } & 27 & 5 & 1,1 \\
\hline & 28 & 31 & 6,9 \\
\hline & 29 & 174 & 38,8 \\
\hline & 30 & 278 & 53,2 \\
\hline
\end{tabular}


When participants' opinions about diagnosis being told to patient were examined, it was found that $72.5 \%$ of the participants considered that the patient should be told the truth. In addition, the responses given for different situations in Scenario 1 were found to be statistically significant in terms of some sociodemographic variables (Table 2).

Table 2. Scenario 1: Suppose you have advanced stage cancer that can't be treated.

\begin{tabular}{|c|c|c|c|c|}
\hline \multicolumn{5}{|c|}{$\begin{array}{l}\text { Situation 1.1. The doctor should inform you about your disease. The doctor should let you decide whether or not to } \\
\text { disclose this information to vour family Do you aaree? }\end{array}$} \\
\hline \multicolumn{2}{|c|}{ Sociodemographic characteristics } & $n(\%)$ * & I agree ${ }^{\star \star} \mathrm{n}(\%)$ & $\mathrm{P}$ \\
\hline Age Group & $65-7475$ or above & $\begin{array}{l}305(68.1) \\
143(31.9)\end{array}$ & $\begin{array}{r}226(74) \\
99(69.2)\end{array}$ & 0,01 \\
\hline Education & $\begin{array}{r}\text { Primary school or below } \\
\text { Middle - High school } \\
\text { University or above }\end{array}$ & $\begin{array}{r}232(52) \\
64(14,2) \\
152(33,8) \\
\end{array}$ & $\begin{array}{r}157(67.6) \\
34(53.1) \\
134(88.1) \\
\end{array}$ & 0,05 \\
\hline Social Security & $\begin{array}{l}\text { Yes } \\
\text { No }\end{array}$ & $\begin{array}{r}372(83) \\
76(17) \\
\end{array}$ & $\begin{array}{r}279(75) \\
46(60.5) \\
\end{array}$ & 0.01 \\
\hline Marital Status & $\begin{array}{r}\text { Married } \\
\text { Single } \\
\end{array}$ & $\begin{array}{l}280(62,5) \\
168(37,5) \\
\end{array}$ & $\begin{array}{r}240(85.7) \\
85(50.8) \\
\end{array}$ & 0,001 \\
\hline \multicolumn{5}{|c|}{$\begin{array}{l}\text { Situation 1.2. The doctor should inform your family about your disease, and not you. Your family should decide } \\
\text { whether you should be told about your disease. Do you agree? }\end{array}$} \\
\hline \multicolumn{2}{|c|}{ Sociodemographic characteristics } & $n(\%)$ * & | agree ${ }^{\star \star} \mathrm{n}(\%)$ & $\mathrm{P}$ \\
\hline Age Group & $65-7475$ or above & $\begin{array}{l}305(68.1) \\
143(31.9)\end{array}$ & $\begin{array}{l}75(24.5) \\
55(38.4)\end{array}$ & 0.001 \\
\hline Education & $\begin{array}{r}\text { Primary school or below } \\
\text { Middle - High school } \\
\text { University or above }\end{array}$ & $\begin{array}{r}232(52) \\
64(14,2) \\
152(33,8) \\
\end{array}$ & $\begin{array}{r}95(40.9) \\
29(45.3) \\
16(0.1) \\
\end{array}$ & 0.0001 \\
\hline Marital Status & $\begin{array}{r}\text { Married } \\
\text { Single }\end{array}$ & $\begin{array}{l}280(62,5) \\
168(37,5)\end{array}$ & 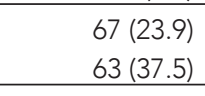 & 0.01 \\
\hline Income Status & $\begin{array}{r}\text { Less than expenses } \\
\text { Equal to expenses } \\
\text { More than expenses }\end{array}$ & $\begin{array}{r}134(29,9) \\
238(53,1) \\
76(17) \\
\end{array}$ & $\begin{array}{l}50(37.3) \\
70(29.4) \\
10(13.1) \\
\end{array}$ & 0.005 \\
\hline
\end{tabular}

Situation 1.3. Suppose your family is aware of your illness and that they don't want the doctor to give you information about your illness. The doctor should still inform you about your illness. Do you agree?

\begin{tabular}{|c|c|c|c|c|}
\hline \multicolumn{2}{|c|}{ Sociodemographic characteristics } & \multirow{2}{*}{$\begin{array}{c}n(\%) \text { * } \\
305(68.1) \\
143(31.9)\end{array}$} & \multirow{2}{*}{$\begin{array}{r}\text { I }_{\text {agree }}^{* \star} \mathrm{n}(\%) \\
226(74) \\
99(69.2)\end{array}$} & \multirow{2}{*}{$\begin{array}{r}P \\
0,01\end{array}$} \\
\hline Age Group & $65-7475$ or above & & & \\
\hline Education & $\begin{array}{r}\text { Primary school or below } \\
\text { Middle - High school } \\
\text { University or above }\end{array}$ & $\begin{array}{r}232(52) \\
64(14,2) \\
152(33,8)\end{array}$ & $\begin{array}{r}157(67.6) \\
34(53.1) \\
134(88.1)\end{array}$ & 0,05 \\
\hline Social Security & $\begin{array}{l}\text { Yes } \\
\text { No }\end{array}$ & $\begin{array}{r}372(83) \\
76(17) \\
\end{array}$ & $\begin{array}{r}279(75) \\
46(60.5) \\
\end{array}$ & 0.01 \\
\hline Marital Status & $\begin{array}{r}\text { Married } \\
\text { Single }\end{array}$ & $\begin{array}{l}280(62,5) \\
168(37,5)\end{array}$ & $\begin{array}{r}240(85.7) \\
85(50.8) \\
\end{array}$ & 0,001 \\
\hline Gender & $\begin{array}{r}\text { Female } \\
\text { Male }\end{array}$ & $\begin{array}{l}277(61.8) \\
171(38.2)\end{array}$ & $\begin{array}{l}163(58.8) \\
151(88.3)\end{array}$ & 0.005 \\
\hline
\end{tabular}

*Column percentage **Row percentage 
According to the answers in scenario 2, it is seen that being familiar with the physician for a long time is important for elderly individuals. In addition, the responses given for different situations in Scenario 2 were found to be statistically significant in terms of some sociodemographic variables (Table 3 ).

Table 3. Scenario 2: Suppose you have gastric cancer that will result in death within six weeks and you have pain that can't be relieved. You ask the doctor for a large dose and amount of painkillers to end your life.

Situation 2.1. Let us assume that the doctor is seeing you for the first time and receives general information about your illness.

Situation 2.1.1. The doctor should give you this large dose and amount of medication. Do you agree?

\begin{tabular}{|c|c|c|c|c|}
\hline \multicolumn{2}{|c|}{ Sociodemographic characteristics } & $n(\%)$ * & I agree ${ }^{\star \star} \mathrm{n}(\%)$ & $\mathrm{P}$ \\
\hline Age Group & $65-7475$ or above & $\begin{array}{l}305(68.1) \\
143(31.9)\end{array}$ & $\begin{array}{l}80(26.2) \\
67(46.8)\end{array}$ & 0,001 \\
\hline Education & $\begin{array}{r}\text { Primary school or below } \\
\text { Middle - High school } \\
\text { University or above }\end{array}$ & $\begin{array}{r}232(52) \\
64(14,2) \\
152(33,8 \\
\end{array}$ & $\begin{array}{l}96(41.3) \\
21(32.8) \\
30(19.7) \\
\end{array}$ & 0,001 \\
\hline Marital Status & $\begin{array}{r}\text { Married } \\
\text { Single }\end{array}$ & $\begin{array}{l}280(62,5) \\
168(37,5)\end{array}$ & $\begin{array}{r}100(35.7) \\
47(27.9)\end{array}$ & 0,001 \\
\hline Income Status & $\begin{array}{l}\text { Less than expenses } \\
\text { Equal to expenses } \\
\text { More than expenses }\end{array}$ & $\begin{array}{r}134(29,9) \\
238(53,1) \\
76(17) \\
\end{array}$ & $\begin{array}{r}40(29.8) \\
96(40.33) \\
11(14.4) \\
\end{array}$ & 0.01 \\
\hline
\end{tabular}

Situation 2.2. The same situation, but this time, let us assume that the doctor has known you for 20 years.

Situation 2.2.1. The doctor should give you this large dose and amount of medication. Do you agree?

\begin{tabular}{|c|c|c|c|c|}
\hline \multicolumn{2}{|c|}{ Sociodemographic characteristics } & $n(\%)$ * & I agree ${ }^{\star \star} n(\%)$ & $P$ \\
\hline Age Group & $65-7475$ or above & $\begin{array}{l}305(68.1) \\
143(31.9)\end{array}$ & $\begin{array}{r}180(59) \\
64(44.7)\end{array}$ & 0.05 \\
\hline Education & $\begin{array}{r}\text { Primary school or below } \\
\text { Middle - High school } \\
\text { University or above }\end{array}$ & $\begin{array}{r}232(52) \\
64(14,2) \\
152(33,8) \\
\end{array}$ & $\begin{array}{r}165(71.1) \\
25(39) \\
54(35.5) \\
\end{array}$ & 0.005 \\
\hline Marital Status & $\begin{array}{r}\text { Married } \\
\text { Single }\end{array}$ & $\begin{array}{l}280(62,5) \\
168(37,5)\end{array}$ & $\begin{array}{r}200(71.4) \\
44(26.1)\end{array}$ & 0.0001 \\
\hline Social Security & $\begin{array}{l}\text { Yes } \\
\text { No }\end{array}$ & $\begin{array}{r}372(83) \\
76(17)\end{array}$ & $\begin{array}{r}230(61.8) \\
14(18.4)\end{array}$ & 0.0001 \\
\hline
\end{tabular}

*Column percentage **Row percentage

Based on the answers given to Scenario 3, it was determined that $79 \%(n=354)$ of the participants thought about leaving a living will and appointing a medical proxy. 
Table 4. Scenario 3. Let us assume that your condition has suddenly worsened one day because of your illness and that you are unable to make decisions on medical interventions to be performed on you. In such a case, you talked to your family when your health was still good, you told your family about any interventions you didn't want to be performed (e.g. cardiopulmonary resuscitation, respiratory support, etc.), but your family doesn't support your thoughts.

\begin{tabular}{|c|c|c|c|c|}
\hline \multicolumn{2}{|c|}{ Sociodemographic characteristics } & \multirow{2}{*}{$\begin{array}{c}n(\%) \text { * } \\
305(68.1) \\
143(31.9)\end{array}$} & \multirow{2}{*}{$\begin{array}{r}\text { | }^{\text {agree }}{ }^{\star *} \mathrm{n}(\%) \\
270(88.5) \\
84(58.7)\end{array}$} & \multirow{2}{*}{$\begin{array}{r}P \\
0,05\end{array}$} \\
\hline Age Group & $65-7475$ or above & & & \\
\hline Education & $\begin{array}{r}\text { Primary school or below } \\
\text { Middle - High school } \\
\text { University or above }\end{array}$ & $\begin{array}{r}232(52) \\
64(14,2) \\
152(33,8)\end{array}$ & $\begin{array}{r}150(64.6) \\
59(92.1) \\
145(95.3)\end{array}$ & 0,05 \\
\hline Marital Status & $\begin{array}{c}\text { Married } \\
\text { Single }\end{array}$ & $\begin{array}{l}280(62,5) \\
168(37,5)\end{array}$ & $\begin{array}{r}240(85.7) \\
84(50)\end{array}$ & 0,001 \\
\hline
\end{tabular}

${ }^{*}$ Column percentage ${ }^{\star \star}$ Row percentage

When the responses given by the participants to the scenarios are examined, it can be seen that age group, education, and marital status are common variables that are statistically significant in all scenarios $(P \leq 0.05)$.

\section{DISCUSSION}

The main purpose of planning end-of-life treatment and care decisions in advance is to ensure that patient, family, and physician discuss the best treatment options and are prepared for certain medical conditions, and make the best possible medical decisions at the time (11). One of the most important problems in the physician-patient relationship in our country is that the decisions for the treatment are mostly taken by the relatives and/or physician of the patient instead of the patient. This situation becomes more evident in the decisions taken about the termination of life (12). In their cross-cultural study comparing attitudes of American, Japanese, Arab and Turkish physicians regarding the last period of life, Buken and Odabasi (2013) found that the fact that physicians knew their patients caused differences in attitudes about physician-assisted suicide. However, knowing the patient for a long time in Saudi Arabia, which is a Muslim country like ours, did not change the physician attitude regarding physician-assisted suicide $(13,14)$. In other Islamic countries such as ours, the common thought about end-of-life treatment and care is that if the treatment will not improve the patient's condition or quality of life, life support can be interrupted or terminated. It has been reported that the patient population at the end of life is largely comprised of older adults. However, even if life support is terminated, nutrition is not terminated or interrupted. Even with the possibility of Double Effect, pain relief is advocated but euthanasia is never accepted. The fact that the physician knows its patient has been reported to accelerate the decision-making process in the treatment and care protocol (15). In study of Kellog et al. found that the physician and the patient who were familiar with each other facilitated the end-of-life treatment and care process. Because the doctor knows the treatment preferences of the patient he or she has known for years, and it was found that the majority of elderly people wanted to be told about their medical diagnoses (78\%) (16). Kelner's study in Canada showed that a large proportion of patients (76\%) wanted to be told 
about their medical diagnosis and take active role in medical treatment decisions (17). In this respect, the results of present study are consistent with the literature, and it was found that the majority of elderly participants in Turkey wanted to know their medical diagnoses and be a decision maker when making medical decisions (Table 2, Table 3).

Based on the results of our study, it was found that $79 \%$ of the participants would consider leaving a living will after being explained what a living will was (Scenario 3). Although these concepts are new in Turkey and we don't see them often in practice, the situation in other countries isn't so different either. During their interviews in Canada, Heyland et al. found that $76.3 \%$ of elderly thought about end-of-life decisions before being hospitalized but only $11.9 \%$ acted on these thoughts and left a living will, 30.3\% discussed these decisions with physicians (18). In the study of Gamble et al. in North Carolina, it was found that $64 \%$ knew what living will was, none of them filled out a living even though the government had a program related to it, and only two participants (3\%) discussed endof-life treatment and care preferences living their doctors. In the same study, it was found that 93\% of the participants wanted to have a family member or spouse as their medical proxy when they couldn't make decisions for themselves (4). In another study of 76 elderly individuals in the UK, it was found that $82 \%$ of the participants didn't hear the terms of living will, instructions, or advanced directives before, and only 4 people out of 13 who had heard what living will be correctly defined the term, and $75 \%$ of the participants preferred relatives or spouses, $5 \%$ preferred friends, and $20 \%$ preferred their doctors as medical proxy (19). In our study, these rates were $58.9 \%$ for family, $38.6 \%$ for physician, and $2.5 \%$ for friends. In addition, we found that married participants, aged between 65 and 74 years, with social security and a university education or above wanted to take an active part in their end-of-life treatment preferences, they wanted to be informed first about their diagnosis, and they wanted to decide whether the diagnosis should be told to the family (Table 2, Situation 1.1). It was determined that elderly individuals who had more income than their expenses didn't agree with the idea that the medical diagnosis should be told to the family first and the family should decide whether the diagnosis should be told to them or not (Table 2, Situation 1.2). It was also found that male participants between the ages of 65 and 74, with social security and a university education or above considered that the physician should inform them about their diseases even if their family didn't want this information to be disclosed to them (Table 2, Situation 1.3). Similar to our findings, when we look at other studies in the literature, we see that married elderly people with high educational level and above average income status want to play an active role in end-of-life treatment and care decisions, and think that the medical diagnosis should be told to them as it will create a pressure and burden on family members and spouses (5, $17,19)$. On the other hand, regarding the practices in some Middle Eastern countries, it is known that undesirable diagnosis is reported to the family and then to the patient in Iran, and the family decides to tell the diagnosis to the patient (20). tendency to act in line with the principle of beneficence is common in Saudi Arabia, but family members are reported to be given priority in telling about the diagnosis of the disease (21). In our study, we determined that patients who have been familiar with their physicians for a long time think that the physicians should fulfill their wishes and requests. Based on the answers given to Scenario 2, it was found that being familiar with the physician for a long time was a factor in fulfilling the request for high doses of painkillers and they thought that the physician should give them these high doses of drugs since they had been familiar with the physician for a long time (Table 3). As well as in our study, the research in Hacettepe, mentioned above, revealed that knowing the physician for a long time increased the rate of asking for high doses of pain killer (7). Kellog also found that elderly people who 
are familiar with their physicians talk about their end-of-life treatment and care preferences more easily with their physicians and think that the physician should fulfill their wishes (16). In terms of living will and appointing a medical proxy, we found that married participants between the ages of 65 and 74 with a university education or above were considering leaving a living will and appointing a medical proxy, which was consistent with the literature (Table 4) $(11,16,18)$.

Within the traditional social structure of Turkey, it is the duty of first-degree relatives (spouses, children, grandchildren, etc.) to look after the elderly in the family who are in need of care, and decisions about elderly are largely made by those who assume this responsibility, with the idea that the elderly will benefit from them. All kinds of problems are discussed with the person or people who assume the care needs of elderly individuals. Although this is regarded as normal for elderly individuals who are unable to make decisions on their behalf, the fact that the family doesn't know what the elderly individual would decide on if he or she were able to make a decision puts the family under a moral burden. Our results and other studies in literature show that family and patient decisions often contradict with each other. There-

\section{REFERENCES}

1. Chrash M, Mulich B, Patton CM. The APN role in holistic assessment and integration of spiritual assessment for advance care planning. J Am Acad Nurse Pract 2011;23:530-6. DOI: 10.1111/j.17457599.2011.00644.x Accessed: 27.08.2019.

2. Buken NO, Buken E. Aging case and medical ethics. Turkish Journal of Geriatrics 2003 Feb 24;6(2):759. [Internet] Available from: http://geriatri.dergisi. org/uploads/pdf/pdf_TJG_147.pdf. Accessed: 27.08.2019.

3. Kaspers PJ, Philipsen BDO, Deeg DJH, et al. Decisionmaking capacity and communication about care of older people during their last three months of life. BMC Palliat Care 2013;12:1-10. (PMID: 23305093). fore, elderly individuals filling out a statement of authorization will eliminate the dilemmas associated with the appointment of a medical proxy and end-of-life treatment and care decisions. During the provision of health services, the standards of courtesy, providing information, and dealing with the health, well-being, and peace of a person shouldn't change according to age. Based on the results of our study, not talking to elderly individuals with the judgment that they will not understand the concepts of elderly care, not seeing them as a decision-maker in treatment and care decisions, allowing close relatives to make the decisions and applying these decisions are unacceptable attitudes, especially for elderly people with good mental health. The most important point here is to ensure that elderly people take part in decision making processes by establishing the right communication channel, preparing an appropriate communication environment, explaining things to the elderly in a language that they will understand and repeating these often if necessary, allowing them to ask questions, and, if necessary, providing psychological support. Fair treatment not only necessitates equal treatment, but also providing patients with different treatment options, if necessary, based on their specific needs.

4. Gamble ER, McDonald PJ, Lichstein PR. Knowledge, attitudes, and behavior of elderly persons regarding living wills. Arch Intern Med 1991;515:277-80. (PMID: 1992955).

5. Piers R, Albers G, Gilissen J, et al. Advance care planning in dementia: recommendations for healthcare professionals. BMC Palliative Care 2018;17(88):1-17. DOI: 10.1186/s12904-018-0332-2

6. Republic of Turkey, Ministry of Health, Patient Rights Regulations. [Internet] Available from: www.mevzuat.gov.tr/Metin .Aspx?MevzuatKod= 7.5.4847\&Mevzuatlliski= $\quad$ 0\&sourceXmlSearch $=$ hasta\%20haklar\%C4\%B1 Accessed: 02.02.2020.

7. Odabaşı $A B$, Buken NO. Informed Consent and Ethical Decision Making in the end of life: Hacettepe 
Example. Turkiye Klinikleri J Med Sci 2009;29(5):104154. [Internet] Available from: https://www. turkiyeklinikleri.com/article/tr-aydinlatilmis-onamve-yasamin-sonunda-alinan-etik-kararlar-hacettepeornegi-56088.html Accessed: 23.02.2020.

8. Folstein MF, Folstein S, Mc Hugh PR. "Mini Mental State" A practical method for grading the cognitive state of patients for the clinician. J Psychiatr Res 1975;12:189-98. (PMID: 1202204).

9. Güngen C, Ertan T, Eker E, Yaşar R, Engin F. Reliability and Validity of The Standardized Mini Mental State Examination in The Diagnosis of Mild Dementia in Turkish Population. Turkish Journal of Psychiatry 2002;13(4):273-81. (PMID: 12794644).

10. Ruhnke GW, Wilson SR, Akamatsu T, et al. Ethical decision making and patient autonomy: a comparison of physicians and patients in Japan and the United States. Chest 2000;118:1172-82. (PMID: 11035693).

11. Sudore RL, Fried TR. Redefining the 'planning' in advance care planning: preparing for end-of-life decision making. Ann Intern Med 2010;153(4):256261. (PMID: 20713793).

12. Buken NO. Yoğun bakım ünitelerinde etik karar verme ve hastane etik komiteleri. Flora/ Infeksiyon Hastalıkları ve Klinik Mikrobiyoloji Dergisi 2011;16(2):51-60 [Internet] Available from: http://www. floradergisi.org/fulltext.aspx?issue_id=166\&ref_ind_ id=667 Accessed: 04.02.2020.

13. Buken NO, Balseven-Odabasi A. Physicians' attitudes at the end-of-life: a cross-cultural evaluation. Med Law 2013;32:549-65. (PMID: 24552115).
14. Mobeireek AF, Al-Kassimi F, Al-Zahrani K, et al. Information disclosure and decision-making: the Middle East versus the Far East and the West. J Med Ethics 2008;34:225-29. (PMID: 18375670).

15. Sachedina A. End-of-life: the Islamic view. Lancet 2;366:774-9. (PMID: 16125596).

16. Kellogg FR, Crain M, Corwin J, Brickner PW. Lifesustaining interventions in frail elderly persons: talking about choices. Arch Intern Med 1992;152:2317-20. (PMID: 1444692).

17. Kelner M. Activists and delegators: Elderly patients' preferences about controlat the end of life. Soc Sci Med 1995;41:537-45. (PMID: 7481948).

18. Heyland DK, Barwich D, Pichora D, et al. ACCEPT (Advance Care Planning Evaluation in Elderly Patients) Study Team; Canadian Researchers at the End of Life Network (CARENET) Failure to engage hospitalized elderly patients and their families in advance care planning. JAMA Intern Med 2013:173:778-87. (PMID: 23545563).

19. Schiff R, Rajkumar C, Bulpitt C. Views of elderly people on living wills: interview study. British Medical Journal 2000;320:1640-6. (PMID: 10856065).

20. Ghavamzandeh A, Bahar B. Communication with the cancer patient in Iran. Ann NY Acad Sci 2000;913:2615. (PMID: 9103577).

21. Younge D, Moreau P, Ezzat A, Gray A. Communicating with cancer patients in Saudi Arabia. Ann NY Acad Sci 1997;809:309-16. (PMID: 9103582). 